\title{
Tabungan Literasi Berbasis Kearifan Lokal (Tali Kekal) sebagai Solusi Penanaman Minat Literasi Siswa
}

\author{
Sugeng Santoso ${ }^{1}$, Ivan Hadi Prawira Negara ${ }^{2}$, Sabina Salsabila ${ }^{3}$, \\ Alfatikha Ainia Prihadi ${ }^{4}$, Prahoro Yudo Purwono ${ }^{5}$ \\ Universitas Pendidikan Ganesha $^{1,2,}$ Universitas Pendidikan Indonesia ${ }^{3}$, \\ Universitas Negeri Yogyakarta $^{4}$, Universitas Negeri Surabaya ${ }^{5}$ \\ Korespondensi: sugengsantoso18@undiksha.ac.id ${ }^{1}$, ivan.hadi@undiksha.ac.id ${ }^{2}$, \\ sabinasalsabila@upi.edu ${ }^{3}$, alfatikhaainia.2017@ @student.uny.ac.id ${ }^{4}$, \\ prahoro.17020504011@mhs.unesa.ac.id ${ }^{5}$
}

\begin{abstract}
Literacy activities are one of the important components in the progress of education. However, in the midst of the Covid-19 pandemic literacy in Indonesia has decreased. This was exacerbated by the cessation of the Gerakan Literasi Sekolah activities which were intensified by the government, due to the implementation of online learning. This research aims to describe the design of the development of Tabungan Literasi Berbasis Kearifan Lokal (Tali Kekal) in the form of a digital application. Tali Kekal itself was previously a dedication program for inculcating an interest in reading which was implemented in all SD/MI in Pengambengan Village, Jembrana Regency. This research used a qualitative exploratory design. The used of exploratory type because the development is still limited in the form of ideas/designs, and a qualitative approach is used because the data presented uses sentences, not numbers. The results showed that the features contained in the Eternal Rope were, (1) prize claim; (2) library; (3) reading assignments/deposits; (4) savings book; (5) about Indonesia; and (6) folklore. These features are almost similar to conventional Tali Kekal that have been implemented, and these features are considered capable of being a solution in rebuilding online literacy activities in the midst of the Covid-19 pandemic. To maximize the purpose of Tali Kekal, parents must train and assist students in literacy at home.
\end{abstract}

Keywords: literacy, local wisdom, Tali Kekal, students

\begin{abstract}
Abstrak
Kegiatan literasi adalah salah satu komponen penting dalam kemajuan pendidikan. Namun di tengah pandemi Covid-19, literasi di Indonesia kian lesu. Hal tersebut diperparah dengan berhentinya kegiatan Gerakan Literasi Sekolah yang digencarkan oleh pemerintah, karena pemberlakuan pembelajaran daring. Penelitian ini bertujuan untuk mendeskripsikan desain pengembangan Tabungan Literasi Berbasis Kearifan Lokal (Tali Kekal) dalam bentuk aplikasi digital. Tali Kekal sendiri sebelumnya adalah program pengabdian penanaman minat baca yang diterapkan di semua SD/MI di Desa Pengambengan, Kabupaten Jembrana. Penelitian ini menggunakan rancangan eksploratif kualitatif. Jenis eksploratif digunakan karena pengembangan masih sebatas dalam bentuk gagasan/desain, dan pendekatan kualitatif digunakan karena data yang dipaparkan menggunakan kalimat, bukan numerasi. Hasil penelitian menunjukkan bahwa fitur-fitur yang ada dalam Tali Kekal adalah, (1) klaim hadiah; (2) perpustakaan; (3) tugas/setor baca; (4) buku tabungan; (5) seputar Indonesia; dan (6) cerita rakyat. Fitur-fitur tersebut hampir mirip dengan Tali Kekal konvensional yang telah dilaksanakan, dan fitur-fitur tersebut dianggap mampu menjadi solusi dalam membangun kembali kegiatan literasi daring di tengah pandemi Covid-19. Untuk memaksimalkan tujuan dari Tali Kekal, orang tua diharapkan senantiasa melatih dan mendampingi siswa dalam berliterasi di rumah.
\end{abstract}

Kata kunci: kearifan lokal, literasi, Tali Kekal, siswa 
Sugeng Santoso, Ivan Hadi Prawira Negara, Sabina Salsabila, AlfatikhaAinia Prihadi, \& Prahoro Yudo Purwono

\section{A. Pendahuluan}

Irianto \& Febrianti (2017) menyatakan bahwa zaman yang semakin berkembang menuntut mutu pendidikan harus semakin baik pula. Tuntutan tersebut harus terpenuhi karena Indonesia perlu menyiapkan diri untuk bersaing di tengah globaliasi. Ditambah lagi, pada tahun 2030-2045 nanti Indonesia akan mendapatkan bonus demografi berupa jumlah penduduk usia produktif yang mendominasi. Oleh karena itu, pendidikan berkualitas diperlukan untuk mengubah bonus demografi menjadi keuntungan demografi, bukan bencana demografi.

Di saat negara sedang membutuhkan pendidikan yang berkualitas, pandemi yang datang justru menghambat dan mengacaukan sistem pendidikan. Pembelajaran daring yang diterapkan membuat siswa lebih dekat dengan ponsel, bukan bahan bacaan, sehingga kegiatan literasi kian lesu (Rojaki, 2021). Kelesuan tersebut juga terjadi karena kurangnya kesadaran anak dan orang tua untuk berliterasi (Ramadhan, 2021). Padahal, literasi memiliki kedudukan yang krusial dalam baik-buruknya kualitas pendidikan, karena kemampuan literasi yang baik dapat membantu siswa dalam memahami dan mengkaji sebuah sumber bacaan (suatu ilmu). Pentingnya literasi juga diungkapkan oleh Abidin (2020), menurutnya budaya literasi adalah hal yang penting dalam menciptakan masyarakat yang cerdas, hingga kelak akan terbentuk bangsa yang unggul dan berkualitas.

Untuk merangsang minat literasi siswa, sudah banyak gagasan dan cara yang dilakukan/dikembangkan oleh pemerintah serta masyarakat. Seperti Gerakan Literasi Sekolah (GLS), pengadaan pojok baca, hingga pembentukan komunitas peduli membaca. Namun rupanya cara-cara tersebut belum cukup optimal dalam menumbuhkan minat baca. Sebelumnya, penulis yang tergabung dalam Tim KKN Undiksha di Desa Pengambengan, Kecamatan Negara, Kabupaten Jembrana, tahun 2019 sudah menggagas sebuah gerakan penanaman minat baca yang diberi nama "Tabungan Literasi Berbasis Kearifan Lokal (Tali Kekal)".

Kegiatan Tali Kekal sebelumnya sudah dilaksanakan di 6 SD yang ada di Desa Pengambengan pada saat dilaksanakannya KKN. Konsep kegiatan Tali Kekal adalah menstimulus minat membaca siswa melalui buku tabungan berbasis kearifan lokal (Tim KKN Undiksha Desa Pengambengan, 2019). Fungsi buku tabungan adalah untuk mencatat hasil bacaan siswa berdasarkan pada penyampaian hasil bacaan. Nantinya, jika poin buku tabungan sudah mencapai di angka tertentu, siswa dapat menukarkannya dengan hadiah yang disediakan oleh sekolah.

Dalam perumusannya, unsur kearifan lokal turut dicatut karena selaras dengan misi peningkatan kualitas mutu pendidikan sembari melestarikan budaya leluhur. Mengingat, saat ini gejolak arus globalisasi dan modernisasi telah mengikis kecintaan anak bangsa pada kebudayaan lokal (Santoso, 2018). Adapun unsur kearifan lokal yang dimasukkan dalam buku tabungan Tali Kekal adalah berupa pencantuman latar belakang gambar budaya-budaya di Indonesia, seperti tarian, baju adat, dan cerita rakyat. Selain itu, orientasi bacaan cerita rakyat juga sangat difasilitasi dalam kegiatan ini, karena cerita rakyat adalah kekayaan lokal yang sangat relevan dengan kegiatan literasi. Walaupun demikian, siswa dalam Tali Kekal juga sangat diperkenankan membaca sumber bacaan jenis lainnya. 
Saat ini diketemukan informasi bahwa beberapa guru masih menerapkan kegiatan tersebut, dan minat baca siswa cukup membaik. Hal tersebut terlihat dari masih adanya siswa yang menyetor bacaan. Namun, semua itu terhenti karena pemberlakuan pembelajaran daring. Sekarang menanamkan minat literasi bukan lagi menjadi fokus guru. Ketidakmungkinan untuk bertemu secara tatap muka juga turut menghambat kegiatan Tali Kekal. Maka dari itu, diperlukan konsep Tali Kekal yang mendukung jarak jauh. Sehingga, dibuatlah gagasan aplikasi Tali Kekal dalam bentuk digital sebagai bentuk pengembangan dari Tali Kekal konvensional yang telah ada. Pembuatan gagasan aplikasi ini didasarkan pada perkembangan teknologi yang semakin pesat. Bahkan, menurut Santoso \& Negara (2021), pembuatan aplikasi android di era ini sangat relevan dengan kondisi kemajuan teknologi sekarang, di mana manusia memiliki ketergantungan yang tinggi pada teknologi.

Arah penelitian ini adalah membuat dan memaparkan gagasan berupa konsep aplikasi Tali Kekal, berdasarkan kegiatan Tali Kekal konvensional yang sudah pernah dilakukan penulis. Adapun tujuan penelitian ini tak hanya untuk memberikan gambaran tentang gagasan aplikasi yang diangkat, melainkan juga untuk memberikan rujukan untuk penelitian sejenis selanjutnya.

\section{B. Metode}

Rancangan penelitian yang digunakan dalam penelitian ini adalah eksplotarif kualitatif. Penelitian eksploratif adalah penelitian dilakukan dengan mencari tahu secara mandalam suatu fenomena, dan kemudian diberikan hipotesis (Raco, 2010). Dalam penelitian ini, jenis penelitian eksploratif digunakan untuk menganalisa permasalahan literasi, yang dalam hal ini diketemukan bahwa pelaksanaan Tali Kekal terhambat. Lalu, selanjutnya dibuatlah gagasan pemecahannya yang sesuai dengan keadaan saat ini (berupa gagasan aplikasi). Lebih lanjut lagi, mengenai pendekatan yang digunakan, menurut Semiawan (2010) pendekatan kualitatif adalah pendekatan penelitian yang bertujuan menggamparkan suatu fenomena menggunakan kalimat. Pendekatan ini sangat sesuai dengan penelitian yang dilakukan, karena tidak menggunakan analisis numerasi. Alasan pengembangan Tali Kekal digital masih dilakukan sebatas gagasan disebabkan oleh tingginya biaya membuat aplikasi. Maka dari itu, penelitian ini akan berfungsi sebagai gambaran dalam membuat pemecahan yang lebih lanjut. Adapun tahapan yang dilakukan dalam membuat konsep gagasan aplikasi Tali Kekal adalah melalui perancangan menu dan fungsi, membuat desain, dan pendeskripsian.

\section{Hasil dan Pembahasan}

\section{Kegiatan Tali Kekal Sebelum Pandemi}

Sebelum pandemi Covid-19, kegiatan Tali Kekal sudah diterapkan di semua SD dan MI yang ada di Desa Pengambengan, Kecamatan Negara, Kabupaten Jembrana. Adapun yang menjadi pelaksana dalam hal ini adalah penulis yang tergabung dalam Tim KKN Undiksha di Desa Pengambengan. Dalam pelaksanaannya, jenjang pendidikan SD dipilih karena siswa pada usia ini berada pada pendidikan kelas dasar, sehingga masih mudah dibentuk karakter dan sikapnya. Hal ini sesuai dengan terori 
Sugeng Santoso, Ivan Hadi Prawira Negara, Sabina Salsabila, AlfatikhaAinia Prihadi, \& Prahoro Yudo Purwono

tabularasa John Locke (dalam Sativa, 2011) yang menyatakan bahwa perkembangan anak dipengaruhi oleh faktor lingkungan. Anak juga dapat diibaratkan sebagai kertas putih yang dapat ditulisi apa saja sesuai dengan keinginan pendidik.

Adapun jumlah SD dan MI yang ada adalah sejumlah 6 sekolah. Kegiatan ini dilaksanakan pada tahun 2019. Adapun fasilitator dalam kegiatan ini adalah Mahasiswa KKN Universitas Pendidikan Ganesha (Undiksha) yang berada di Desa Pengambengan. Konsep dari kegiatan Tali Kekal adalah mendorong minat membaca siswa melalui poin yang disimpan dalam buku tabungan. Buku tabungan tersebut dihiasi dengan ornamen atau gambar-gambar berbasis kearifan lokal daerah, untuk sekaligus melestarikan budaya lokal yang ada di daerah tertentu.

Kegiatan ini memiliki runtutan yang terdiri atas persiapan, sosialisasi dan perizinan, penerapan, serta penutup. Tahap persiapan dilakukan dengan membuat buku tabungan yang nantinya akan dibagikan kepada siswa. Dalam tahap ini, buku tabungan dibuat dalam bentuk lembaran. Para pelaksana sengaja tidak membuat buku tabungan dalam bentuk buku karena pemangkasan biaya pengenalan. Tahap selanjutnya, sosialisasi dan perizinan. Tahap ini dilakukan dengan cara mendatangi sekolah-sekolah yang akan dijadikan target penerapan. Setelah mendapat perizinan dari sekolah-sekolah terkait, maka pelaksana berani melanjutkan ke tahap selanjutnya. Tahap ketiga, penerapan, dilakukan dengan mengajak siswa di sekolah membaca dan memaparkan kembali isi bacaan. Nantinya siswa akan diberi poin yang dapat ditukar dengan hadiah. Tahap akhir, penutup. Penutup dilakukan dengan membagikan hadiah untuk siswa-siswa terbaik, yang dilangsungkan pada penutup KKN. Pemilihan siswasiswa penerima penghargaan dalam kegiatan pengenalan Tali Kekal dilakukan dengan memilih satu siswa terbaik di tiap-tiap sekolah.

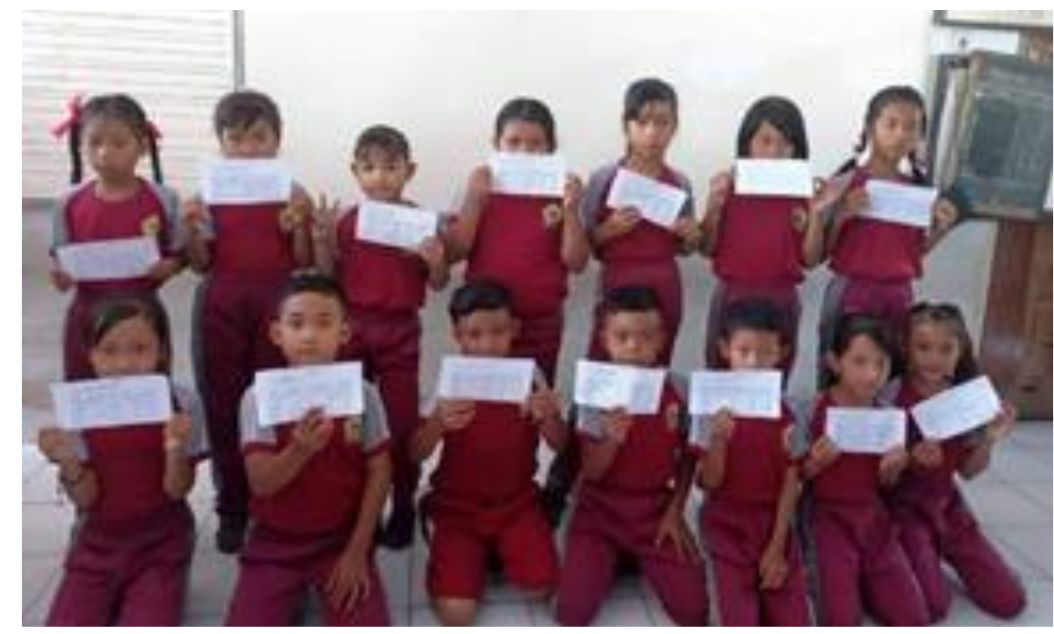

Gambar 1. Dokumentasi Kegiatan Tali Kekal Sebelum Pandemi

Kegiatan Tali Kekal di Desa Pengambengan tak berhenti di situ saja. Setelah kegiatan usai, guru-guru juga dibekali panduan untuk melaksanakan Tali Kekal sendiri. Hadiah yang diperuntukkan kepada siswa didapatkan melalui anggaran sekolah. Sebelum pandemi, masih terdapat beberapa guru yang menerapkan program

ACITYA BHAKTI, Volume 2 Nomor 1, Februari 2022 
Tali Kekal. Namun, sayangnya kini semua terhenti karena pembelajaran yang tidak bisa dilaksanakan tatap muka.

\section{Gagasan Tali Kekal Digital}

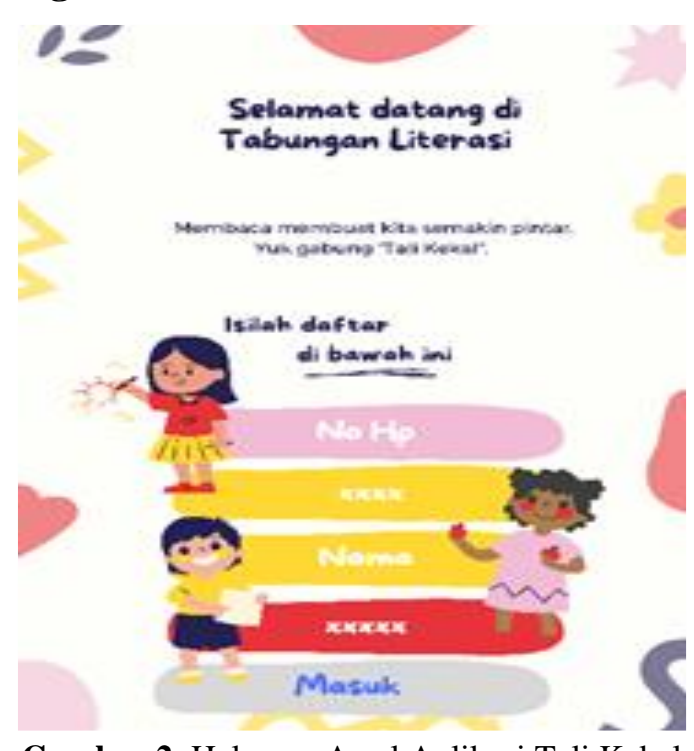

Gambar 2. Halaman Awal Aplikasi Tali Kekal

Untuk mengatasi keberhentian Tali Kekal karena pandemi, maka dibuatlah Tali Kekal versi digital. Dalam penelitian ini, pengembangan yang dilakukan masih pada tahap desain gagasan saja. Berdasarkan tampilan di atas, jika ingin mendaftar Tali Kekal, siswa cukup mengisikan nomor ponsel dan nama mereka. Nantinya, guru akan dapat membuat akun khusus untuk guru yang memiliki fitur pengelola dan pemantau siswa. Guru akan dapat memasukkan siswa dalam daftar kelola melalui web Tali Kekal menggunakan nomor siswa yang sudah terdaftar. Oleh karena itu, diperlukan akses internet untuk menggunakan Tali Kekal.

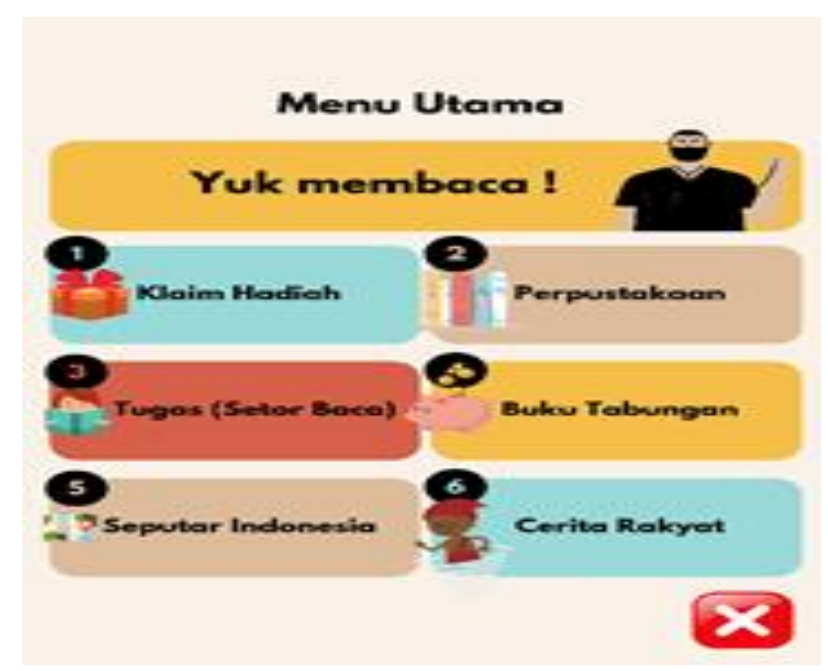

Gambar 3. Fitur-fitur Aplikasi Tali Kekal 
Sugeng Santoso, Ivan Hadi Prawira Negara, Sabina Salsabila, AlfatikhaAinia Prihadi, \& Prahoro Yudo Purwono

Untuk mendukung penanaman minat literasi siswa di tengah pandemi, Tali Kekal memiliki beberapa fitur. Fitur-fitur tersebut di antaranya adalah (1) klaim hadiah; (2) perpustakaan; (3) tugas/setor baca; (4) buku tabungan; (5) seputar Indonesia; dan (6) cerita raykat. Secara lebih lengkapnya, fitur yang ada akan dipaparkan sebagai berikut.

Pertama, klaim hadiah. Untuk menambah semangat siswa dalam belajar dan membaca buku, guru dapat memberikan penghargaan kepada siswa. Penghargaan yang diberikan tidak perlu berbentuk hadiah yang besar dan mahal, cukup hadiah kecil dan sederhana. Penghargaan dapat berupa makanan, boneka, buku, ataupun hadiah sederhana lain. Selain menambah semangat, hadiah yang diberikan juga merupakan bentuk apresiasi, sehingga dapat melatih mental siswa agar mau berusaha, tidak malas, dan merasa dihargai oleh lingkungan sekitar. Jika diterapkan di sekolah, maka hadiah dan besaran poin untuk menukar bisa didiskusikan dengan kepala sekolah dan pihak-pihak kesiswaan terkait.

Kedua, perpustakaan. Fitur perpustakaan pada Tali Kekal adalah tempat baca digital yang memiliki berbagai macam jenis bacaan untuk siswa, dengan mayoritas konten bacaan berupa cerita rakyat Indonesia. Dalam perpustakaan ini, siswa dapat memilih cerita mana yang akan dibaca untuk kemudian cerita tersebut ditampilkan dalam buku digital (e-book) yang dapat dibaca via aplikasi android maupun ios.

Ketiga, tugas/setor baca. Melalui fitur ini, siswa akan dapat mengajukan setor bacaan kepada guru. Nantinya guru dapat mengisikan waktu, judul buku, nama penulis, dan poin yang didapat setelah siswa selesai membaca. Pengisian setor baca ini dapat diisikan melalui perangkat guru maupun siswa. Jadi, tidak terbatas pada satu pemilik akun saja. Penyetoran dapat dilakukan melalui suara, video, maupun bertemu secara langsung.

Keempat, buku tabungan. Buku tabungan merupakan fitur di dalam aplikasi Tali Kekal yang difungsikan sebagai media untuk mencatat riwayat bacaan siswa. Dalam buku tabungan ini, terdapat bukti tertulis berupa waktu, judul buku, nama penulis, dan poin yang didapat setelah siswa selesai membaca. Fitur ini juga dapat dijadikan sebagai penanda untuk siswa, guru, atau orang tua mengenai seberapa jauh aktivitas membaca siswa.

Kelima, seputar Indonesia. Fitur ini menampilkan berbagai informasi seputar Indonesia, meliputi kondisi geografis, sejarah negara, identitas bangsa (seperti lambang negara, bendera, dasar negara, hingga lagu kebangsaan), pengetahuan tentang sosial Indonesia, dan sebagainya. Melalui fitur ini pula informasi-informasi lain perihal Indonesia dapat hadir secara berkala, contohnya informasi perihal kebudayaan, makanan tradisional, dan sebagainya. Informasi tersebut tampil dalam bentuk halaman berseri yang dapat dibaca secara bertahap. Selain dalam bentuk halaman bersambung (seri), fitur ini juga dapat menampilkan informasi sekilas Indonesia secara utuh berbentuk sebuah buku digital. Dukungan gambar, infografis, atau hal sejenis dapat menambah daya tarik visual dari fitur ini.

Keenam, cerita rakyat. Sebagai salah satu bentuk keragaman kearifan lokal di Indonesia, fitur cerita rakyat dalam Tali Kekal hadir untuk mengangkat kembali nilainilai lokal dalam pemahaman literasi siswa di suatu daerah. Fitur cerita rakyat dalam Tali Kekal ditampilkan dalam menu dan submenu yang dapat dikategorikan menurut provinsi/daerah, serta jenis cerita rakyat. Jenis cerita rakyat tersebut meliputi legenda,

ACITYA BHAKTI, Volume 2 Nomor 1, Februari 2022 
mite, fabel, dan sage. Versi penyampaian cerita rakyat juga dapat disesuaikan dengan kebutuhan siswa atau jenjang sekolah. Bisa dalam bentuk video, bacaan teks, maupun becaan bergambar.

\section{Harapan dari Tali Kekal Digital}

Gagasan upaya digitalisasi Tali Kekal diharapkan dapat memberi manfaat untuk berbagai elemen dalam dunia pendidikan, khususnya terhadap minat literasi siswa SD. Kegiatan literasi siswa pun diharapkan dapat tetap berlangsung, baik secara digital maupun nondigital. Koneksi antara pengetahuan dan keterampilan siswa berbasis kearifal lokal yang diperoleh diharapkan dapat memberi kontribusi terhadap perkembangan bangsa. Seiring meningkatnya minat literasi siswa, peradaban yang lebih baik diharapkan mampu tercipta melalui penanaman nilai-nilai dalam Tali Kekal. Jika sudah berhasil dikembangkan, nantinya aplikasi ini dapat dinikmati dengan gratis oleh elemen-elemen yang membutuhkan, karena program ini berbasis pengabdian dan pengembangan untuk masyarakat.

\section{Penutup}

\section{Simpulan}

Tali Kekal konvensional yang telah dijalankan dapat dikatakan berhasil, sebelum pandemi datang. Untuk mengatasi kemacetan Tali Kekal karena pandemi maka Tali Kekal digital digagaskan dengan menu, yaitu (1) klaim hadiah; (2) perpustakaan; (3) tugas/setor baca; (4) buku tabungan; (5) seputar Indonesia; dan (6) cerita raykat. Perumusan menu-menu tersebut didasarkan pada analisis kebutuhan siswa, mengenai lemahnya minat membaca dan kearifan lokal yang terus tergerus oleh zaman. Meskipun masih dalam bentuk gagasan, upaya pendigitalisasian Tali Kekal diharapkan dapat memberi manfaat untuk berbagai elemen dalam dunia pendidikan, khususnya terhadap minat literasi siswa. Tentunya manfaat tersebut akan dapat dirasakan setelah dibuat versi final dari aplikasi Tali Kekal yang siap digunakan.

\section{Saran}

Penanaman literasi pada siswa tak cukup hanya dilakukan oleh guru. Dalam hal ini, orang tua juga perlu mengambil peran. Untuk memaksimalkan tujuan dari Tali Kekal, orang tua diharapkan senantiasa melatih dan mendampingi siswa dalam berliterasi di rumah.

\section{DAFTAR PUSTAKA}

Abidin, N.R.Z. (2020). Literasi Membaca sebagai Upaya Pembentuk Karakter Peserta Didik (Jujur dan Bertanggungjawab). Prosiding Seminar Nasional Pascasarjana UNNES.

Irianto, P.O., \& Febrianti, L.Y. (2017). Pentingnya Penguasaan Literasi bagi Generasi Muda dalam Menghadapi MEA. Proceedings of The 1st Education and Language International Conference, Center for International Languange Development of Unissula. 
Sugeng Santoso, Ivan Hadi Prawira Negara, Sabina Salsabila, AlfatikhaAinia Prihadi, \& Prahoro Yudo Purwono

Raco, J. R. (2010). Metode Penelitian Kualitatif. Jakarta: Grasindo.

Ramadhan, F. (2021). Minat Baca Anak Ikut Mati Diterjang Pandemi Covid-19. Kompas. $\quad$ www.kompas.id/baca/humaniora/2021/04/24/baca-anak-ikut-matiditerjang-pandemi.

Rojaki. (2021). Penguatan Literasi di Tengah Kemelut Covid (Refleksi Setahun Pandemi Covid-19). Web SMA Negeri 2 Sekayu. www.sman2sekayu.sch.id/penguatan-literasi-di-tengah-kemelut-covidrefleksi-setahun-pandemicovid-19.

Santoso, S. (2018). Pendidikan Karakter Berbasis Tri Hita Karana untuk Menyongsong Indonesia Emas 2045. Dipresentasikan pada Educreation Universitas Negeri Yogyakarta Tahun 2018.

Santoso, S., \& Negara, I. H. P. (2021). Penanaman Minat Bertani Pada Siswa TK Melalui Aplikasi Edutani. Jurnal Sistema, 2(1). https://doi.org/10.2493/sjp.v21i.733.

Sativa. (2011). Empirisme, Sebuah Pendekatan Penelitian. Jurnal Inersia, 7(2).

Semiawan, C. R. (2010). Metode Penelitian Kualitatif. Grasindo.

Tim KKN Undiksha Desa Pengambengan. (2019). Laporan KKN Desa Pengambengan. [Laporan KKN tidak diterbitkan]. Universitas Pendidikan Ganesha. 